\title{
Two Novel Alliin Lyase (Alliinase) Genes from Twisted-Leaf Garlic (Allium obliquum) and Mountain Garlic (Allium senescens ssp. montanum)
}

\author{
Bogdan DRUGĂ ${ }^{1}$, Dana ŞUTEU ${ }^{1}$, Oana ROŞCA-CASIAN ${ }^{2}$, Marcel PÂRVU ${ }^{2 *}$, Nicolae DRAGOŞ \\ ${ }^{1}$ Institute of Biological Research, 48 Republicii Street, 400015, Cluj-Napoca, Romania \\ ${ }^{2}$ Babes-Bolyai University, Faculty of Biology and Geology, „Alexandru Borza” Botanical Garden, 42 Republicii \\ Street, 400015, Cluj-Napoca, Romania; mparvucluj@yahoo.com ("corresponding author)
}

\begin{abstract}
Alliinase (Alliin lyase EC 4.4.1.4), a pyridoxal phosphate-dependent lyase, represents one of the major protein components of Allium species. The enzyme is a homodimeric glycoprotein and catalyzes the synthesis of allicin (diallyl thiosulfinate, a biologically active compound), pyruvate, and ammonia starting from the specific non-protein sulfur-containing amino acid alliin $((+\mathrm{S})$-allyl-L-cysteine sulfoxide). Using newly developed specific primers two new alliinase genes from Allium obliquum and Allium senescens ssp. montanum were amplified and sequenced, as well as their homologs, from Allium fistulosum and Allium schoenoprasum. The G+C content of the alliinase region ranges between that of other dicot plants and that reported in monocot cereal plants, in all four species. Investigations of gene expression revealed a significantly higher enzyme expression level in bulbs than in leaves in all four taxa. The deduced alliinase sequences displayed a high variability among different species, since the lowest sequence similarity was found to be $55.5 \%$ between Allium senescens ssp. montanum and Allium cepa, while the highest similarity is $77.5 \%$, between Allium senescens ssp. montanum and Allium fistulosum. Leucine is the most common amino acid in all four alliinases, while cysteine is also more frequent than in other enzymes, suggesting a high stability of the molecules due to the possible disulfide bonds.
\end{abstract}

Keywords: allicin, alliinase, mountain garlic, qPCR, twisted-leaf garlic

\section{Introduction}

In onion (Allium cepa), garlic (Allium sativum) and other related Allium species, the characteristic flavor is due to the alliinase enzyme (EC 4.4.1.4). Also known as alliin lyase, or alkyl Cys sulfoxide lyase, it hydrolyzes the $S$-alk(en)yl-l-Cys sulfoxides (alliin) to form pyruvate, ammonia, and sulfur-containing volatiles (allicin) (Lancaster and Collin, 1981; Stoll and Seebeck, 1951). Alliinase was first described in garlic, in 1947 (Stoll and Seebeck, 1947). The alliinase from garlic bulbs was the first one to be purified (Mazelis and Crews, 1968). Its activity is inhibited by hydroxylamine and cysteine, while the addition of pyridoxal phosphate, EDTA, $\mathrm{Mg}^{2+}, \mathrm{Mn}^{2+}, \mathrm{Co}^{2+}$ or $\mathrm{Fe}^{2+}$ stimulates the reaction rate. First DNA sequences of genes encoding for alliinase were reported in Allium sativum (garlic), Allium cepa (onion), and Allium ascalonicum (shallot) (Van Damme et al., 1992). They are highly similar both at the nucleotide and amino acid levels. In garlic, the molecular mass of the enzyme is $51451 \mathrm{Da}$ (Van Damme et al., 1992). Several new alliinases were further purified, displaying a variety of isoforms (Lancaster et al., 2000; Manabe et al., 1998). In Chinese chive (Allium tuberosum), the molecular mass of alliinase is $54083 \mathrm{Da}$, and the deduced amino acid sequence exhibited 66-69\% identity to the reported alliinases of onion, garlic, and shallot. Two isoforms with alliinase activity were isolated from onion, and the gene homology to other reported allium alliinase genes was 50\% (Lancaster et al., 2000).

In some alliinase genes, the $\mathrm{G}+\mathrm{C}$ content is similar to that of dicot plants and lower than that of monocot cereal plants, although onion is a monocot (Do et al., 2003). The three-dimensional structure of the garlic alliinase at $1.5 \AA$ resolution revealed that the active enzyme is a pyridoxal5'-phosphate-dependent homodimeric glycoprotein (Kuettner et al., 2002), while another X-ray structure of the enzyme has improved the understanding of the pyridoxal phosphate binding to the active site (Shimon et al., 2007). A novel heteropentameric alliinase was detected and purified from the roots of the Amazonian medicinal plant Petiveria alliacea (Musah et al., 2009b), the same species displaying a novel lachrymatory factor synthase (LFS) (Musah et al., 2009a), an enzyme active only in the presence of alliinase (Eady et al., 2008). Another alliinase, purified from the bacterium Ensifer adaerens, displays a novel type of substrate specificity (Yutani et al., 2011). Several attempts to elucidate the conditions that may increase the enzyme activity have been carried out. Thus, some evidences suggest that the activity of alliinase might be enhanced by temperature, $\mathrm{pH}$, low frequency, and mild intensity ultrasound (Musah et al., 2009a; Wang et al., 2011; Yutani et al., 2011).

Alliinase can be immobilized through lysine residues on the surface of various matrices to produce allicin (Miron 
294

et al., 2006). Allicin and alliin are well-studied biological compounds, since they may play an important medical role (Freeman and Kodera, 1995; Jones et al., 2004; Miron et al., 2004; Shadkchan et al., 2004). In particular, garlic is the most used alliinase-producing species in cancer therapy (Seki et al., 2008), in cardiovascular protection (OronHerman et al., 2005; Shimon et al., 2007), or in respiratory diseases (Appel et al., 2010; Rose et al., 2005).

In this paper the characterization of two novel bulb and leaf alliinase genes from Allium obliquum and Allium senescens ssp. montanum subsequent to cloning their $\mathrm{cDNA}$ is reported. The genes are slightly different in sequence from other alliinase genes, and the deduced proteins may have novel characteristics compared to other Allium alliinases. The function of these novel alliinases is discussed.

\section{Material and methods}

Plants

Whole fresh plants of Allium obliquum (Twisted-leaf Garlic), Allium senescens ssp. montanum (Mountain Garlic), Allium fistulosum (Welsh Onion) and Allium schoenoprasum (Chives) were collected from natural habitats in Transylvania, Romania, and they were stored at $-80^{\circ} \mathrm{C}$ until further analysis.

New primers design and use

Forty-seven alliinase sequences obtained from GenBank were aligned using CLC Workbench 6.0 (Finlandsgade 10-12, Katrinebjerg 8200 Aarhus N, Denmark). Several new primer pairs were designed based on the consensus sequence of approx. $1700 \mathrm{bp}$ in the alliinase gene region, using PerlPrimer (Marshall, 2004). Moreover, two primer pairs for real-time polymerase chain reaction (qPCR) were designed, targeting a 220 bp alliinase gene fragment (Tab. 1). All primer pairs were first tested using the "in silico PCR" tool of the FastPCR 6.1 software (Kalendar et al. 2009).

\section{$D N A$ and $R N A$ isolation; real time PCR}

Genomic DNA and total RNA were isolated from plant bulbs and leaves using Wizard ${ }^{\circ}$ Genomic DNA Purification Kit and SV Total RNA Isolation System (Promega, Madison, WI, USA), following manufacturer's instructions. Two units of Turbo DN-ase treatment (Ambion Europe, LTD Huntingdon, Cambidgeshire, UK) were applied in order to remove the traces of residual genomic DNA. cDNA was obtained with a First Strand cDNA Synthesis Kit (Fermentas, Burlington, Ontario, Canada) using random primers. Expression of the gene encoding the enzyme alliinase was probed by qPCR with a BioRad iQ5 thermocycler using the two pairs of specific primers (Tab. 1), and using the phosphoenolpyruvate carboxylase gene as reporter, by applying a mathematical model (Pfaffl, 2001).
PCR amplification of alliinase and $18 S r R N A$ genes

The PCR assay conditions for the alliinase gene were optimized for the newly designed primers as follows: each $50 \mu \mathrm{l}$ reaction volume included $50 \mathrm{ng}$ cDNA template, 5 $\mu \mathrm{l} 10 \mathrm{X}$ buffer with $\left(\mathrm{NH}_{4}\right)_{2} \mathrm{SO}_{4}$ (Fermentas), dNTPs (200 $\mu \mathrm{mol} / \mathrm{l}), \mathrm{MgCl}_{2}(1.5 \mathrm{mmol} / \mathrm{l})$, primers $(400 \mathrm{nmol} / \mathrm{l})$ and 2.5 U DreamTaq DNA Polymerase (Fermentas). Cycling conditions were: $95^{\circ} \mathrm{C}$ for $2 \mathrm{~min}$, followed by 33 cycles at $93^{\circ} \mathrm{C}$ for $12 \mathrm{sec}, 54^{\circ} \mathrm{C}$ for $22 \mathrm{sec}, 72^{\circ} \mathrm{C}$ for $1 \mathrm{~min}$, with the final elongation of $5 \mathrm{~min}$ at $72^{\circ} \mathrm{C}$.

The $18 \mathrm{~S}$ rRNA gene was amplified with the CV1CV4primer pair (Sawayama et al., 1992) (Tab. 1). $50 \mathrm{ng}$ of genomic DNA were added to $49 \mu \mathrm{l}$ of the amplification mixture, for a final concentration of 1X DreamTaq Buffer (Fermentas), $200 \mu \mathrm{M}$ dNTP mix, $0.4 \mu \mathrm{M}$ of each of the forward and reverse primers, and $1.25 \mathrm{U} / \mu \mathrm{l}$ of DreamTaq Polymerase (Fermentas), in a final volume of $50 \mu \mathrm{l}$. The PCR program included 1 cycle of initial denaturation at $93^{\circ} \mathrm{C}$ for $5 \mathrm{~min}$, followed by 33 cycles with a denaturing step of $30 \mathrm{~s}$ at $95^{\circ} \mathrm{C}$, an annealing step of $30 \mathrm{~s}$ at $57^{\circ} \mathrm{C}$, and an elongation step of $1 \mathrm{~min}$ at $72^{\circ} \mathrm{C}$. The final elongation was done for $5 \mathrm{~min}$ at $72^{\circ} \mathrm{C}$.

All PCR products were separated on $1 \%$ agarose gel in a $1 \mathrm{x}$ TAE running buffer, stained with ethidium bromide $(1 \mu \mathrm{g} / \mathrm{ml})$ and visualized by transillumination. The FastRuler $^{\text {mo }}$ Middle Range DNA Ladder (Fermentas) was used to measure the PCR product size. Each PCR was performed 3-5 times.

\section{Cloning and sequencing of a partial alliinase cDNA and} $18 S$ rRNA genes

PCR products were purified with the Wizard ${ }^{\circ}$ SV Gel and PCR Clean-Up System (Promega) and then cloned into the pGEM-T vector using the pGEM-T vector system (Promega). Plasmid DNA was isolated using a the Wizard ${ }^{\circ}$ Plus SV Minipreps DNA Purification System (Promega) from colonies that had the correct insert size, as determined by PCR with M13 forward and reverse primers. Sequencing reactions were performed using a terminator cycle sequencing kit (ABI PRISM Big Dye kit, Perkin-Elmer Applied Biosystems, Foster City, CA, USA) and analyzed on an ABI PRISM 3100 Genetic Analyzer. All the resulted fragments were deposited in the GenBank database under accession number JN797255-JN797262.

\section{Bioinformatic analysis}

The $18 \mathrm{~S}$ rRNA nucleotide sequences generated in this study were aligned with other 40 similar fragments from GenBank using CLC Workbench 6.0 (Finlandsgade 1012, Katrinebjerg 8200 Aarhus N, Denmark). The alignment was used to generate a phylogenetic tree with 31 different sequences (the multiple sequences belonging to same species were removed, so that each species was represented by one single sequence), with the $18 \mathrm{~S}$ rRNA gene of Lacistema aggregatum (a dicot species) as outgroup. 
Translated amino acid sequences of alliinases were generated using ExPaSy (Gasteiger et al., 2003), starting from the fragments amplified with the newly designed primers. These sequences, together with other alliinase available sequences (GenBank, NCBI) were aligned using CLC Workbench 6.0, in order to identify similarities/differences between them. Moreover, all the enzyme sequences obtained from the four studied species were analyzed with regard to their isoelectric point, molecular weight, and topology, using the corresponding tools on the ExPaSy web site (Gasteiger et al., 2003).

\section{Results}

\section{Analysis of alliinase and $18 \mathrm{~S} r \mathrm{R} A$ genes}

A fragment of approx. $1700 \mathrm{bp}$ of the alliinase gene was successfully amplified with the new primers using cDNA as template (Fig. 1a). Similarly, a 2000 bp fragment was generated with the CV1-CV4 primer pair during the PCR amplification of the 18S rRNA gene using genomic DNA as template (Fig. 1b). The length of the PCR amplified fragments matched the one expected from in silico amplification using FastPCR 6.1 software (1705-1731 bp) (Tab. 1).

Four different alliinase genes were amplified and sequenced from the four studied species. In each species, the gene from the bulb was identical to the one from the leaves. The length of gene sequences obtained from the four species ranged from 1728 (in Allium obliquum) to $1788 \mathrm{bp}$ (in Allium schoenoprasum), close to the average length of other monocots alliinase genes.

The $\mathrm{G}+\mathrm{C}$ content of the analyzed alliinase genes is: 40,9\% in Allium obliquum, 41,7\% in Allium senescens ssp. montanum, 43,5\% in Allium fistulosum, 43,6\% in Allium schoenoprasum, and very similar to the one found in $\mathrm{Al}$ lium sativum $(39,9 \%)$. Overall, the $\mathrm{G}+\mathrm{C}$ content of the four alliinase regions ranges between the $33 \%$ of the other genomic regions in dicot plants and the $45 \%$ reported in monocot cereal plants.

The phylogenetic analyses based on the 18S rRNA sequences have grouped the four species studied in the present work into a single cluster with a bootstrap value of 85 (Fig. 2). Among all the species in the tree, it seems that Agapanthus africanus and Bebnia reticulata are the closest related species to the Allium genus. The single dicot species included in the tree, Lacistema aggregatum, was grouped apart from all the other species, with a maximum bootstrap value of 100 .

\section{$q P C R$}

The expression of bulb and leaf alliinase genes in four species was also investigated: Allium obliquum, Allium senescens ssp. montanum, Allium fistulosum and Allium schoenoprasum. It was revealed that the enzyme located in the bulb is expressed at a higher level than in leaves in all four of them. Thus, the bulb:leaves expression ratio is 6.8:1 in Allium obliquum, 3.4:1 in Allium senescens ssp. montanum, 5:1 in Allium fistulosum, and 3.3:1 in Allium schoenoprasum.

\section{Analysis of the amino acid sequences}

The deduced alliinase amino acid sequence from $\mathrm{Al}$ lium obliquum and Allium senescens ssp. montanum were aligned with other alliinase amino acid sequences of $\mathrm{Al}$ lium. Homology with Allium cepa alliinase is $59.4 \%$ for Allium obliquum and 55.5\% for Allium senescens ssp. montanum, respectively. Homology with garlic (Allium sativum) clove alliinase is $71.4 \%$ and $68.5 \%$ (Van Damme et al., 1992). Homology with shallot (Allium ascalonicum) is $71.8 \%$ and $65.4 \%$, and with chinese chives (Allium tuberosum) homology is $69.4 \%$ and $74.3 \%$ (Manabe et al., 1998). When compared with the other two Allium species

Tab. 1 The primers used during this study. F2-All + R2-All and F3-ALL + R3-ALL were used to amplify the entire alliinase gene, while F1_int-ALL and F2_int-ALL were used as internal primers in order to sequence the gene. The FqPCR1-ALL + RqPCR1ALL primer pair amplified an approx. $220 \mathrm{bp}$ fragment of the alliinase gene for the qPCR analyses. The CV1 + CV4 primer pair was used to amplify the $18 \mathrm{~S}$ rRNA gene and to sequence it, also using the internal primer CV2 (Sawayama et al., 1992). Primers designed here are bolded

\begin{tabular}{|c|c|c|c|}
\hline Primer name & Sequence 5'-3' & $\begin{array}{l}\text { Melting temp. Tm } \\
\left({ }^{\circ} \mathrm{C}\right)\end{array}$ & $\begin{array}{c}\text { Amplicon expected lenght } \\
(\mathrm{bp})\end{array}$ \\
\hline F2-ALL & GAGGCGGTGGCTAATATAAACTG & 57 & \multirow{2}{*}{1731} \\
\hline R2-ALL & TATACGTCCATTCTGGGCAGTCA & 58 & \\
\hline F3-ALL & AGGCAGTGGGGGATATAAACTG & 58 & \multirow{2}{*}{1705} \\
\hline R3-ALL & CGTCCATTCTGAAATGTCTGGT & 56 & \\
\hline F1_int-ALL & TTGCTCATGCСССТTATTATCC & 56 & \multirow[b]{2}{*}{ - } \\
\hline F2_int-ALL & TGGAGTATAGGTGGCTCAACTC & 57 & \\
\hline FqPCR1-ALL & GCTCTGCTGATGTTGCCAGGT & 59 & \multirow{2}{*}{221} \\
\hline RqPCR1-ALL & CCACTGCATGCATCATGTAGTG & 58 & \\
\hline CV-1 & TACCTGGTTGATCCTGCCAGTAG & 59 & \multirow{2}{*}{2000} \\
\hline $\mathrm{CV}-4$ & ACCTTGTTACGACTTCTCCTTCСTC & 59 & \\
\hline $\mathrm{CV}-2$ & CCAATCCCTAGTCGGCATCGT & 60 & - \\
\hline
\end{tabular}




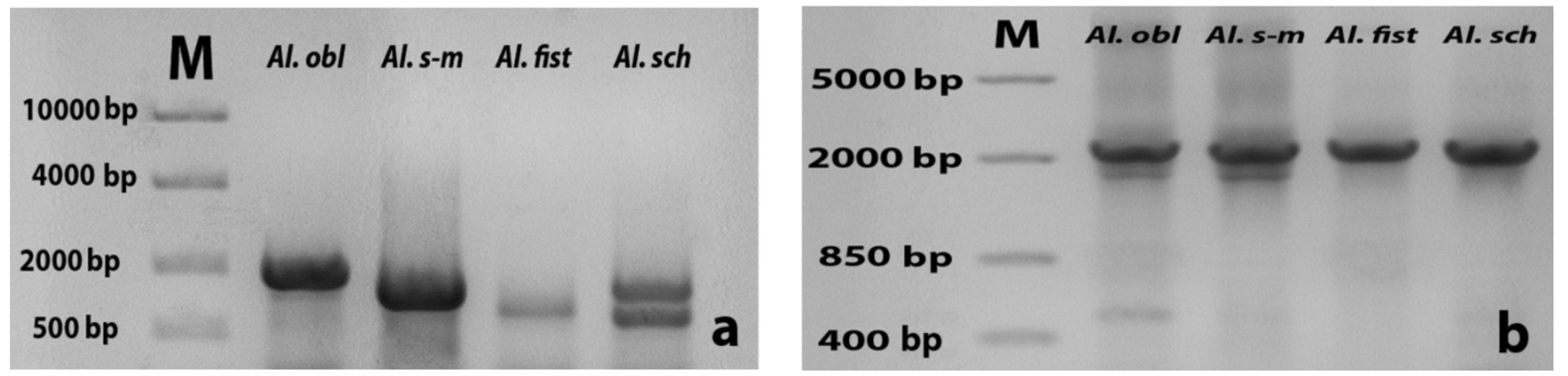

Fig .1. PCR amplification of the alliinase (a) and 18S rRNA (b) genes. The alliinase gene was amplified with new primer pairs, designed during this study, while the 18S rRNA gene was amplified with the CV1-CV4 primer pair (Sawayama et al., 1992). Al. obl = Allium obliquum; Al. s-m = Allium senescens ssp. montanum; Al. fist = Allium fistulosum; Al. sch = Allium schoenoprasum

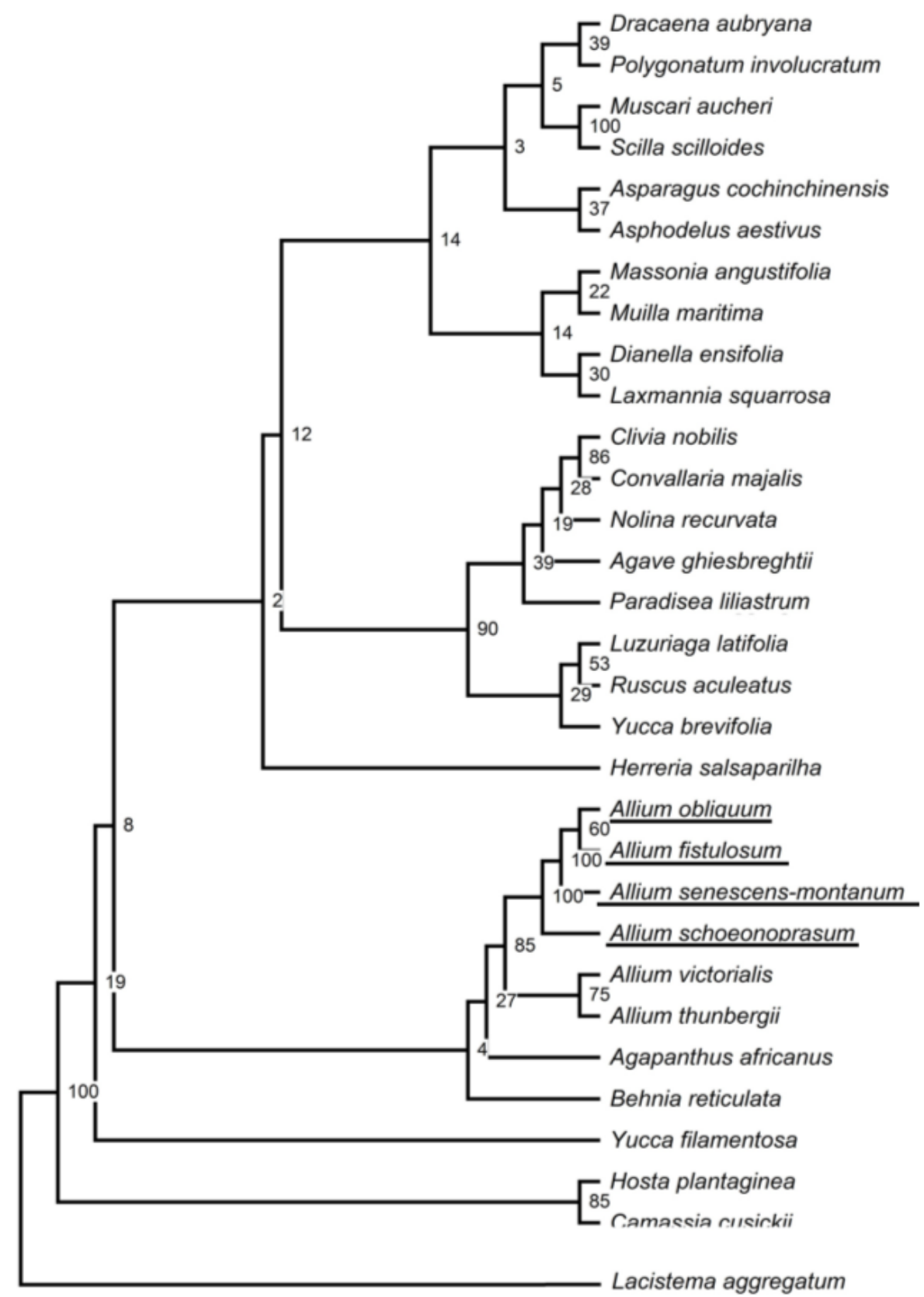

Fig. 2. The phylogenetic tree generated using the Minimum evolution method, with the four Allium species analyzed here being underlined. The bootstrap test was performed in 100 replicates 
studied here, there was revealed that the homology with Allium fistulosum is $77,5 \%$ and $66 \%$, while the homology with Allium schoenoprasum is $56.5 \%$ and $64.8 \%$. The homology between the analyzed species, Allium obliquum and Allium senescens ssp. montanum is $70.5 \%$, while between Allium fistulosum and Allium schoenoprasum the aminoacid sequence homology is $67.4 \%$.

The most frequent amino acid in the four sequenced alliinases is leucine, with about $10 \%$ of the total amino acid pool. Cysteine, one of the most important amino acid in proteins due to its role in stability, is also well represented in two of the four alliinases analyzed here: $4.5 \%$ in Allium fistulosum and $4.9 \%$ in Allium schoenoprasum. In the other two species the pool of cysteine represents 3\% (in Allium obliquum) and 3.1\% in Allium senescens ssp. montanum. However, cysteine is better represented in these species than in garlic (Allium sativum), where it represents only $2.5 \%$ of the total alliinase amino acid pool. The isoelectric point and molecular weight calculated for the four alliinases is: 9.28 and $58440 \mathrm{Da}$ in Allium obliquum, 9.37 and $55123 \mathrm{Da}$ in Allium senescens ssp. montanum, 8.11 and $49554 \mathrm{Da}$ in Allium fistulosum and 8.47 and $49121 \mathrm{Da}$ in Allium schoenoprasum.

\section{Conclusions}

Here there are reported the sequencing and characterization of two novel alliinase genes from Allium obliquum (Twisted-leaf Garlic) and Allium senescens ssp. montanum (Mountain Garlic), in comparison with two other similar genes sequenced from Allium fistulosum (Welsh Onion) and Allium schoenoprasum (Chives). Eight new primers were successfully designed and used: four primers (two pairs) for the PCR amplification of the whole alliinase gene, two primers (one pair) targeting a 221-bp fragment of the alliinase gene for the qPCR analyses, and two forward primers used for sequencing the alliinase gene.

The range of $\mathrm{G}+\mathrm{C}$ content among the alliinases sequenced here gives them a distinct pattern, different from monocots, although these plants are classified into this group. Horizontal gene transfer (HGT) may be responsible for this, together with genetic recombination, a lot of other genomic sequences being relocated this way in plants, even at inter-specific level.

The gene expression investigations revealed that the alliinase enzyme is expressed at a much higher level in bulbs versus leaves in all species that were analyzed here. Particularly in Allium obliquum, the gene expression in bulbs is almost seven-fold higher than in leaves. This conclusion is consistent with the expression pattern of other alliums reported in the literature. The reason why these genes are differentially expressed in related species is still unclear, but it can be speculated that this is in connection with the number/density of the animals that can consume the plants, as long as the lachrymatory factor (synthesized to avoid the plants to be eaten) is active only if the alliinase is also present. However, further studies of gene expression under different growth conditions (variations in soil composition, temperature, light) will probably contribute to the understanding of this expression pattern.

The deduced amino acid sequences of the alliinases described here display a wide range of similarity with other known alliinases. These findings are in accordance with other results from various papers, showing that the alliinase gene displays a high variability among different species. Thus, it can't be used as a phylogenetic marker, but it could easily discriminate between closely related species.

Among the amino acids, leucine is the most frequent one, thus probably increasing the hydrophobicity of the enzyme. Moreover, cysteine is another amino acid whose frequency is higher than in garlic (Allium sativum-2.5\% cysteine) in all four analyzed species. It can be speculated that the alliinases studied here have an enhanced stability due to the disulfide bonds that may form between cysteines. Moreover, the activity of the enzymes could be higher, as long as many metal cofactors in enzymes are bound to the cysteine residues.

\section{Acknowledgement}

This work was supported by CNCSIS-UEFISCSU, project number PNII-IDEI code 2272/2008, and by NUCLEU Programme: PN 0936 (BIODIV).

\section{References}

Appel E, Vallon-Eberhard A, Rabinkov A, Brenner O, Shin I, Sasson K, Shadkchan Y, Osherov N, Jung S, Mirelman D (2010). Therapy of murine pulmonary aspergillosis with antibody-alliinase conjugates and alliin. Antimicrob Agents Chemother 54:898-906.

Do GS, Suzuki G, Mukai Y (2003). Genomic organization of a novel root alliinase gene, ALL1, in onion. Gene 325:17-24.

Eady CC, Kamoi T, Kato M, Porter NG, Davis S, Shaw M, Kamoi A, Imai S (2008). Silencing onion lachrymatory factor synthase causes a significant change in the sulfur secondary metabolite profile. Plant Physiol 147:2096-2106.

Freeman F, Kodera Y (1995). Garlic chemistry: stability of S-(2propenyl) 2-propene-l-sulfinothioate (allicin) in blood, solvents and simulated physiological fluids. J Agric Food Chem 43:2332-2338.

Gasteiger E, Gattiker A, Hoogland C, Ivanyi I, Appel RD, Bairoch A (2003). ExPASy: the proteomics server for indepth protein knowledge and analysis. Nucleic Acids Res 31:3784-3788.

Jones MG, Hughes J, Tregova A, Milne J, Tomsett AB, Collin HA (2004). Biosynthesis of the flavour precursors of onion and garlic. J Exp Bot 55:1903-1918.

Kalendar R, Lee D, Schulman AH (2009). Fast PCR software for PCR primer and probe design and repeat search. Genes, Genomes and Genomics 3:1-14.

Kuettner EB, Hilgenfeld R, Weiss MS (2002). The active 
298 principle of garlic at atomic resolution. J Biol Chem 277:46402-46407.

Lancaster JE, Collin HA (1981). Presence of alliinase in isolated vacuoles and of alkyl cysteine sulfoxides in the cytoplasm of bulbs of onion (Allium cepa). Plant Sci Lett 22:169-169.

Lancaster JE, Shaw ML, Pither Joyce MD, McCallum JA, McManus MT (2000). A novel alliinase from onion roots. Biochemical characterization and cDNA cloning. Plant Physiol 122:1269-1279.

Manabe T, Hasumi A, Sugiyama M, Yamazaki M, Saito K (1998). Alliinase [S-alk(en)yl-L-cysteine sulfoxide lyase] from Allium tuberosum (Chinese chive)-Purification, localization, cDNA cloning and heterologous functional expression. Eur J Biochem 257:21-30.

Marshall OJ (2004). PerlPrimer: cross-platform, graphical primer design for standard, bisulphite and real-time PCR. Bioinformatics 20:2471-2472.

Mazelis M, Crews L (1968). Purification of the alliin lyase of garlic, Allium sativum L. Biochem J 108:725-730.

Miron T, Bercovici T, Rabinkov A, Wilchek M, Mirelman D (2004). [3H]Allicin: preparation and applications. Anal Biochem 331:364-369.

Miron T, SivaRaman H, Rabinkov A, Mirelman D, Wilchek M (2006). A method for continuous production of allicin using immobilized alliinase. Anal Biochem 351:152-154.

Musah RA, He Q, Kubec R (2009a). Discovery and characterization of a novel lachrymatory factor synthase in Petiveria alliacea and its influence on alliinase-mediated formation of biologically active organosulfur compounds. Plant Physiol 151:1294-1303.

Musah RA, He Q, Kubec R, Jadhav A (2009b). Studies of a novel cysteine sulfoxide lyase from Petiveria alliacea: the first heteromeric alliinase. Plant Physiol 151:1304-1316.

Oron-Herman M, Rosenthal T, Mirelman D, Miron T, Rabinkov A, Wilchek M, Sela B-A (2005). The effects of $S$-allylmercaptocaptopril, the synthetic product of allicin and captopril, on cardiovascular risk factors associated with the metabolic syndrome. Atherosclerosis 183:238-243.
Pfaffl MW (2001). A new mathematical model for relative quantification in real-time RT-PCR. Nucleic Acids Res 29:2002-2007.

Rose P, Whiteman M, Moore PK, Zhu YZ (2005). Bioactive $S$-alk(en)yl cysteine sulfoxide metabolites in the genus Allium: the chemistry of potential therapeutic agents. Nat Prod Rep 22:351-368.

Sawayama S, Minowa T, Dote Y, Yokoyama S (1992). Growth of the hydrocarbon-rich alga Botryococcus brannii in secondarily treated sewage. Appl Microbiol Biotechnol 38:135-138.

Seki T, Hosono T, Hosono-Fukao T, Inada K, Tanaka R, Ogihara J, Ariga T (2008). Anticancer effects of diallyl trisulfide derived from garlic. Asia Pac J Clin Nutr 17:249-252.

Shadkchan Y, Shemesh E, Mirelman D, Miron T, Rabinkov A, Wilchek M, Osherov N (2004). Efficacy of allicin, the reactive molecule of garlic, in inhibiting Aspergillus spp. in vitro, and in a murine model of disseminated aspergillosis. J Antimicrob Chemother 53:832-836.

Shimon LJW, Rabinkov A, Shin I, Miron T, Mirelman D, Wilchek M, Frolow F (2007). Two structures of alliinase from Allium sativum L.: Apo form and ternary complex with aminoacrylate reaction intermediate covalently bound to the PLP cofactor. J Mol Biol 366:611-625.

Stoll A, Seebeck E (1947). Alliin, the pure mother substance of garlic oil. Experientia 3:114-115.

Stoll A, Seebeck E (1951). Chemical investigations of alliin, the specific priniciple of garlic. Adv Enzymol 11:377-400.

Van Damme JM, Smeets K, Torrekens S, Van Leuven F, Peumansi WJ (1992). Isolation and characterization of alliinase cDNA clones from garlic (Allium sativum L.) and related species. Eur J Biochcm 209:751-757.

Wang J, Cao Y, Sun B, Wang C, Mo Y (2011). Effect of ultrasound on the activity of alliinase from fresh garlic. Ultrason Sonochem 18:534-540.

Yutani M, Taniguchi H, Borjihan H, Ogita A, Fujita K, Tanaka $\mathrm{T}$ (2011). Alliinase from Ensifer adhaerens and its use for generation of fungicidal activity. AMB Express 1(2):1-8 